\title{
Effects of heat treatments on antioxidant capacity and total phenolic content of four cultivars of purple skin eggplants
}

\author{
Athiwat Chumyam ${ }^{\mathrm{a}}$, Kanda Whangchai ${ }^{\mathrm{a}, \mathrm{b}}$, Jarunee Jungklang ${ }^{\mathrm{a}}$, Bualuang Faiyue ${ }^{\mathrm{c}}$, \\ Kobkiat Saengnil ${ }^{\mathrm{a}, \mathrm{b}, *}$ \\ ${ }^{a}$ Department of Biology, Faculty of Science, Chiang Mai University, Chiang Mai 50200 Thailand \\ b Postharvest Technology Research Institute, Chiang Mai University / \\ Postharvest Technology Innovation Center, Commission on Higher Education, Bangkok 10140 Thailand \\ ${ }^{c}$ Department of Biology, Mahidol Wittayanusorn School, Salaya, Phuttamonthon, \\ Nakhon Pathom 73170 Thailand
}

*Corresponding author, e-mail: kobkiat_s@ hotmail.com

\begin{abstract}
We investigated the effects of three heat treatments on antioxidant capacity and total phenolic content in purple skinned eggplant fruits. Four cultivars of eggplant: 'Muang Lek', 'Muang Lot Fai', 'Muang Kan Dam', and 'Muang Kan Khiao' were subjected to boiling, steaming, and microwaving for 5, 10, and $15 \mathrm{~min}$ in each treatment. The results show that antioxidant capacity (DPPH and ABTS) and total phenolic content significantly increased in all eggplant cultivars with all cooking methods compared with those of raw fruits. Fruits microwaved for 10 and 15 min had the highest antioxidant capacities and total phenolic content in all cultivars. 'Muang Lot Fai' had the highest antioxidant capacity and total phenolic content of the four cultivars examined. A highly positive correlation for each heat treatment was found between antioxidant capacity and total phenolic content.
\end{abstract}

KEYWORDS: boiling, cooking methods, microwaving, steaming, vegetables

\section{INTRODUCTION}

Eggplant (Solanum melongena L.) is a common vegetable consumed throughout the world. It contains important phytonutrients such as phenolic and flavonoid compounds which have high antioxidant capacities $^{1-3}$. Phenolic compounds and antioxidant activity are found in most parts of the eggplant, including calyx, leaf, peel, pulp, and stem ${ }^{3}$. In the fruits, the antioxidant capacities and phenolic compounds are found in both the pulp and skin ${ }^{4}$. The antioxidant capacity and total phenolic content of purple skin eggplants have been reported to be higher than those of green and white skin cultivars ${ }^{5,6}$.

Most vegetables are heated either by boiling, steaming or microwaving before being consumed ${ }^{7}$. Several studies have reported that these heating processes cause many changes in the chemical composition of vegetables. For example, the antioxidant capacity and total phenolic content of pepper ( $\mathrm{Cap}$ sicum spp.), green bean (Phaseolus vulgaris), broccoli (Brassica oleracea), spinach (Spinacia oleracea), and sweet corn (Zea mays) increase after boiling, steaming, or microwaving ${ }^{8,9}$. Heating also increased total phenolic content in pungent peppers (Capsicum аппиит $)^{10}$. In contrast, total phenolic content and antioxidant capacity of tomatoes (Lycopersicon esculentum) decrease by boiling, baking, or frying ${ }^{11}$. The antioxidant capacity and total phenolic content of fresh cut broccoli decrease significantly by microwave heating ${ }^{12}$. The antioxidant capacity of garlic (Allium sativum) decreases by drying and steaming ${ }^{13}$. Also, the phenolic content was found to decrease in nonpungent peppers (Capsicum annuum) by heating ${ }^{10}$.

Eggplant is one of the most common vegetables used in Thai cuisine ${ }^{2}$ and is usually cooked. The objective of our study was to investigate the effects of different heat treatments including boiling, steaming, and microwaving on antioxidant capacities and total phenolic contents of four purple skin eggplant cultivars in Thailand.

\section{MATERIALS AND METHODS}

\section{Plant materials}

Four cultivars of purple skin eggplants (Solanum melongena) at commercial maturity, namely 'Muang Lek', 'Muang Lot Fai', 'Muang Kan Dam', and 

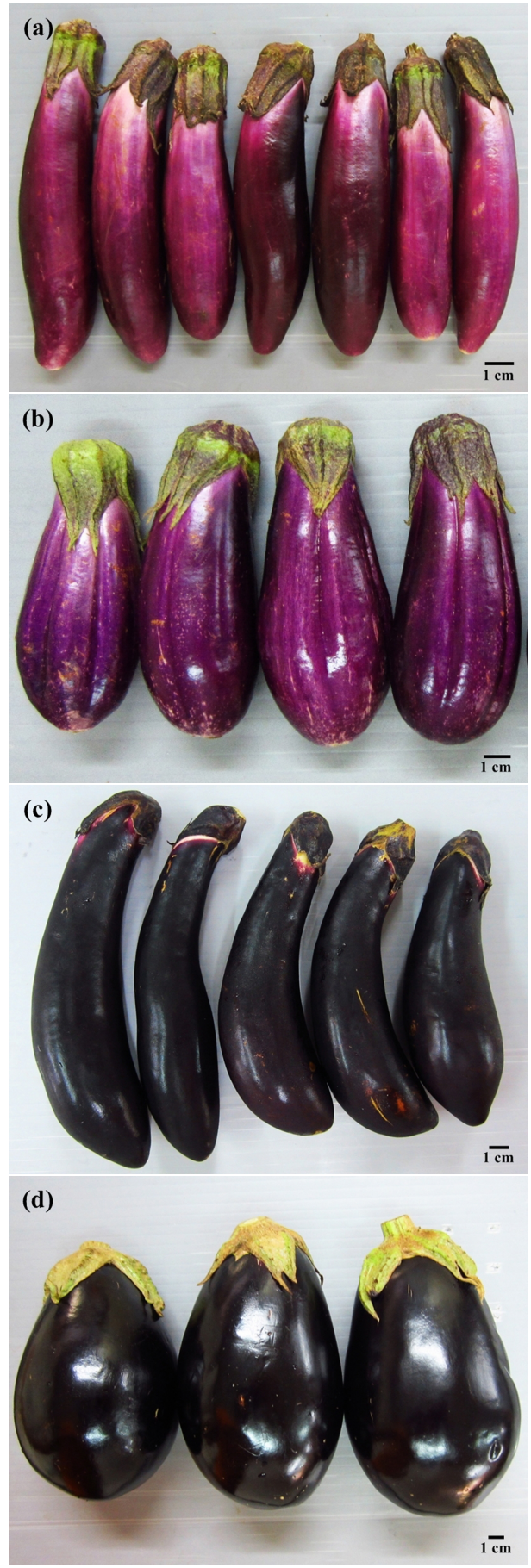

Fig. 1 Four cultivars of purple skin eggplant fruit: (a) 'Muang Lek', (b) 'Muang Lot Fai', (c) 'Muang Kan Dam', (d) 'Muang Kan Khiao'.

'Muang Kan Khiao' (Fig. 1), were purchased from local markets in Chiang Mai, Thailand. The fruits were cleaned with tap water and dried with tissue paper.
Whole fruits were subjected to boiling, steaming, and microwave heating to study antioxidant capacity and total phenolic content. Six fruits were used for each treatment and raw fruits without heating were used as a control.

\section{Boiling process}

The fruits were heated in 21 of boiling water in a commercial pot for 5, 10, and $15 \mathrm{~min}$, respectively, and cooled at room temperature before testing.

\section{Steaming process}

One litre of distilled water was added to a commercial pot (10 1 capacity) with a sieve, and then eggplant fruits were steamed for 5, 10, and $15 \mathrm{~min}$, respectively. After steaming, the heated fruits were cooled at room temperature before testing.

\section{Microwaving process}

Eggplants were placed in a dish covered with a plastic cap and then heated in a microwave oven (Goldstar ER-762MD, $700 \mathrm{~W}$ ) for 5, 10, and $15 \mathrm{~min}$. After microwaving, the heated fruits were cooled at room temperature before testing.

\section{Extraction of samples}

Samples were extracted by the modified method of Ahmed and Osama ${ }^{14}$. Flesh and skin of each heated or raw fruit of eggplants were cut into small pieces. A sample $(1 \mathrm{~g})$ was then homogenized for $1 \mathrm{~min}$ in $25 \mathrm{ml}$ of $80 \%$ methanol by using a mortar and pestle at $4{ }^{\circ} \mathrm{C}$. The extract solution was centrifuged at $15950 \mathrm{~g}$ for $20 \mathrm{~min}$ at $4{ }^{\circ} \mathrm{C}$ (Herml model Z383K, Germany) and the supernatant was collected as a sample solution to determine antioxidant capacities and total phenolic contents.

\section{DPPH radical scavenging capacity assay}

The DPPH method was carried out according to the procedure of Mun'im et $\mathrm{al}^{15}$ with slight modifications. The principle of this assay is that the free radical $\mathrm{DPPH}^{\bullet}$ possesses a characteristic absorption at $517 \mathrm{~nm}$, which decreases significantly on exposure to antioxidants by receiving hydrogen atoms or electrons. A lower absorbance at $517 \mathrm{~nm}$ indicates a higher antioxidant capacity of the extract ${ }^{16}$. The method is a standard assay in antioxidant capacity studies and offers a rapid technique for analysing the antioxidant capacity of extracts. In our study, the sample extract $(100 \mu \mathrm{l})$ was mixed with $400 \mu \mathrm{l}$ of $0.3 \mathrm{M}$ acetate buffer $\mathrm{pH} 5.5$ in a test tube. Then $2.5 \mathrm{ml}$ of $0.12 \mathrm{mM} \mathrm{DPPH}^{\circ}$ in $100 \%$ methanol was added to the tube. The mixed solution was placed in 
a dark at room temperature $\left(25^{\circ} \mathrm{C}\right)$ for $30 \mathrm{~min}$. The radical scavenging capacity was calculated from the difference in absorbance at $517 \mathrm{~nm}$ between a blank and the sample using a spectrophotometer (Thermo Spectroni model Helios Epsilon, USA). The blank was determined without a sample solution and $100 \%$ methanol was used as a control. A standard curve of $0-1000 \mu \mathrm{M}$ Trolox was used to quantify the antioxidant capacity and the antioxidant capacity was expressed as $\mu \mathrm{mol}$ Trolox equivalents/100 $\mathrm{g}$ of fresh weight.

\section{Determination of ABTS radical scavenging capacity}

The ABTS method was carried out according to the procedure of Huang et $\mathrm{al}^{17}$ with slight modifications. The antioxidant capacities of the sample were determined by measuring a decrease in the intensity of the blue colour of the $\mathrm{ABTS}^{++}$radical as a result of a reaction between the $\mathrm{ABTS}^{\circ+}$ radical and the antioxidant compounds in the sample ${ }^{18}$. In our assay, the $\mathrm{ABTS}^{\circ+}$ radical was generated by persulphate oxidation of ABTS. Specifically, $7 \mathrm{mmol}$ of ABTS ammonium was dissolved in water and treated with $2.45 \mathrm{mmol}$ of potassium persulphate and the mixture was kept at $5{ }^{\circ} \mathrm{C}$ for $16 \mathrm{~h}$ to give a dark blue solution. The dark blue solution was diluted with $80 \%$ ethanol until the absorbance at $734 \mathrm{~nm}$ was read as 0.7 using a spectrophotometer (Thermo Spectroni model Helios Epsilon, USA); this solution was called the ABTS ${ }^{\circ+}$ solution. Then, $2 \mathrm{ml}$ of the $\mathrm{ABTS}^{*+}$ solution was mixed with $20 \mu \mathrm{l}$ of sample. The absorbance at $734 \mathrm{~nm}$ was read at $10 \mathrm{~min}$ after mixing. The radical scavenging capacity was calculated from the difference in absorbance at $734 \mathrm{~nm}$ between the blank and the sample. The blank was determined without a sample solution and $80 \%$ methanol was used as a control. The antioxidant capacity was expressed as $\mu$ mol Trolox equivalents/100 $\mathrm{g}$ of fresh weight as described above.

\section{Determination of total phenolic content}

Total phenolic content was determined by the FolinCiocalteu methods according to the procedures of Singleton and Rossi ${ }^{19}$ with slight modifications. Two $\mathrm{ml}$ of sample extract were mixed with $10 \mathrm{ml}$ of $10 \%$ Folin-Ciocalteu's phenol reagent in a flask and placed at room temperature for $8 \mathrm{~min}$. Then, $8 \mathrm{ml}$ of $7.5 \% \mathrm{Na}_{2} \mathrm{CO}_{3}$ was added to the flask. The mixed solution was placed at room temperature for $2 \mathrm{~h}$. The absorbance was measured at $765 \mathrm{~nm}$ using a spectrophotometer (Thermo Spectroni model Helios Epsilon, USA). A mixture of distilled water and reagents was used as a blank. A standard curve of 0
$100 \mu \mathrm{g} / \mathrm{ml}$ gallic acid was used to quantify the total phenolic content. The total phenolic content was expressed as $\mathrm{mg}$ gallic acid equivalents $/ 100 \mathrm{~g}$ of fresh weight.

\section{Statistical analysis}

Experiments were repeated twice and similar results were obtained. The results of one representative experiment are shown and the data are presented as mean. Differences between treatments were considered at $p<0.05$ by One Way ANOVA using SPSS for Windows version 15.0 .

\section{RESULTS AND DISCUSSION}

As shown in Table 1 , the antioxidant capacity by DPPH radical scavenging assay in eggplant fruits of all cultivars significantly $(p<0.05)$ increased when the fruits were heated with either by boiling, steaming, or microwaving compared with the control fruits (without heating). Microwaving for 5, 10, or 15 min showed higher antioxidant capacities than those of steaming and boiling methods in all cultivars (Table 1). The antioxidant capacity in fruits heated with a microwave increased and reached the highest at $10 \mathrm{~min}$; then the antioxidant capacity reached a plateau (Table 1). Among four cultivars, 'Muang Lot Fai' had the highest antioxidant capacity (Table 1). The antioxidant capacity in 'Muang Lot Fai' at $10 \mathrm{~min}$ of microwave heating was $1.3,1.4$, and 1.2 times higher than that of 'Muang Lek', 'Muang Kan Dam', and 'Muang Kan Khiao', respectively. For steaming, it was found that the highest antioxidant capacities of cultivars 'Muang Lek' and 'Muang Kan Dam' were at 10 min of heating, whereas 'Muang Lot Fai' and 'Muang Kan Khiao' had the highest capacity at $15 \mathrm{~min}$. The antioxidant capacities activated by steaming were still lower than those by microwaving (Table 1). For the boiling treatment, 'Muang Lek' and 'Muang Kan Dam' showed the highest antioxidant capacity at $10 \mathrm{~min}$, whereas 'Muang Lot Fai' and 'Muang Kan Khiao' were highest at $15 \mathrm{~min}$. These antioxidant levels were still lower than those by microwaving (Table 1). The results also showed that an increase in antioxidant capacities by steaming was higher than that of boiling method when the fruits were heated for 5,10 , or $15 \mathrm{~min}$. It is worth mentioning that fruits cooked for $5-15 \mathrm{~min}$ by steaming and boiling were consumable, whereas fruits cooked by a microwave for $15 \mathrm{~min}$ were unpalatable according to Thai eating preferences.

The ABTS radical scavenging assay revealed that antioxidant capacities of eggplants heated by boiling, steaming or microwaving had the same trend as with 
Table 1 Antioxidant capacity and total phenolic content after different heat treatments of four cultivars of eggplant fruits.

\begin{tabular}{|c|c|c|c|c|c|c|c|c|c|c|c|c|}
\hline \multirow{3}{*}{$\begin{array}{l}\text { Cultivar/ } \\
\text { heat } \\
\text { treatment }\end{array}$} & \multicolumn{8}{|c|}{ Antioxidant capacity ( $\mu \mathrm{mol}$ Trolox equivalent $/ 100 \mathrm{~g}$ fresh weight) } & \multirow{2}{*}{\multicolumn{4}{|c|}{$\begin{array}{l}\text { Total phenolic content (mg gallic } \\
\text { acid equivalent } / 100 \mathrm{~g} \text { fresh weight) }\end{array}$}} \\
\hline & \multicolumn{4}{|c|}{ DPPH radical scavenging assay } & \multicolumn{4}{|c|}{ ABTS radical scavenging assay } & & & & \\
\hline & $0 \min$ & $\min$ & $10 \min$ & $15 \mathrm{~min}$ & 0 & $5 \mathrm{~min}$ & $10 \mathrm{~min}$ & $15 \min$ & $0 \mathrm{~min}$ & $5 \mathrm{~min}$ & $10 \mathrm{~min}$ & $15 \mathrm{~min}$ \\
\hline \multicolumn{13}{|l|}{ 'Muang Lek' } \\
\hline Boiling & $55.2^{\mathrm{d}}$ & $89.3^{\mathrm{c}}$ & $160.1^{\mathrm{a}}$ & $133.7^{\mathrm{b}}$ & $8.8^{\mathrm{d}}$ & $14.9^{\mathrm{c}}$ & $25.7^{\mathrm{a}}$ & $22.8^{\mathrm{b}}$ & $78.3^{\mathrm{d}}$ & $113.0^{\mathrm{c}}$ & $166.2^{\mathrm{a}}$ & $145.6^{\mathrm{b}}$ \\
\hline Stea & $55.2^{\mathrm{c}}$ & $121.4^{\mathrm{b}}$ & $169.3^{\mathrm{a}}$ & $161.1^{\mathrm{a}}$ & $8.8^{\mathrm{c}}$ & $16.3^{\mathrm{b}}$ & $29.1^{\mathrm{a}}$ & $28.1^{\mathrm{a}}$ & $78.3^{\mathrm{d}}$ & $136.2^{\mathrm{c}}$ & $174.5^{\mathrm{a}}$ & $150.7^{\mathrm{b}}$ \\
\hline Microwaving & $55.2^{\mathrm{c}}$ & $148.7^{\mathrm{b}}$ & $205.3^{\mathrm{a}}$ & $202.1^{\mathrm{a}}$ & $8.8^{\mathrm{c}}$ & $22.1^{\mathrm{b}}$ & $35.6^{\mathrm{a}}$ & $36.2^{\mathrm{a}}$ & $78.3^{c}$ & $155.2^{\mathrm{b}}$ & $207.7^{\mathrm{a}}$ & $200.0^{\mathrm{a}}$ \\
\hline \multicolumn{13}{|c|}{ 'Muang Lot Fai' } \\
\hline Boiling & $58.4^{\mathrm{d}}$ & $93.5^{\mathrm{c}}$ & $116.0^{\mathrm{b}}$ & $164.2^{\mathrm{a}}$ & $10.6^{\mathrm{c}}$ & $12.2^{\mathrm{c}}$ & $20.2^{\mathrm{b}}$ & $26.0^{\mathrm{a}}$ & $125.4^{\mathrm{d}}$ & $147.3^{\mathrm{c}}$ & 213 & $264.0^{\mathrm{a}}$ \\
\hline Ste & $58.4^{\mathrm{d}}$ & $120.3^{\mathrm{c}}$ & $152.7^{\mathrm{b}}$ & $202.3^{\mathrm{a}}$ & $10.6^{\mathrm{c}}$ & $15.2^{\mathrm{b}}$ & $27.4^{\mathrm{a}}$ & $30.3^{\mathrm{a}}$ & $125.4^{\mathrm{d}}$ & $201.1^{\mathrm{c}}$ & & $334.3^{\mathrm{a}}$ \\
\hline Microwaving & $58.4^{\mathrm{c}}$ & $185.6^{\mathrm{b}}$ & $266.3^{\mathrm{a}}$ & $269.1^{\mathrm{a}}$ & $10.6^{\mathrm{c}}$ & $25.3^{\mathrm{b}}$ & $40.5^{\mathrm{a}}$ & $41.1^{\mathrm{a}}$ & $125.4^{\mathrm{c}}$ & $298.9^{\mathrm{b}}$ & $386.4^{\mathrm{a}}$ & $389.4^{\mathrm{a}}$ \\
\hline \multicolumn{13}{|c|}{ 'Muang Kan Dam' } \\
\hline Boiling & $44.1^{\mathrm{d}}$ & 63. & $121.4^{\mathrm{a}}$ & $95.3^{\mathrm{b}}$ & $10.0^{\mathrm{b}}$ & $13.1^{\mathrm{b}}$ & $19.4^{\mathrm{a}}$ & $17.4^{\mathrm{a}}$ & $98.8^{\mathrm{c}}$ & $108.0^{\mathrm{c}}$ & 174 & $140.0^{\mathrm{b}}$ \\
\hline Stea & $44.1^{\mathrm{c}}$ & $93.2^{\mathrm{b}}$ & $134.3^{\mathrm{a}}$ & $102.4^{\mathrm{b}}$ & $10.0^{\mathrm{d}}$ & $16.9^{c}$ & $25.7^{\mathrm{a}}$ & $20.8^{\mathrm{b}}$ & $98.8^{\mathrm{d}}$ & $125.4^{\mathrm{c}}$ & $196.6^{\mathrm{a}}$ & $145.3^{\mathrm{b}}$ \\
\hline Microwaving & $44.1^{\mathrm{c}}$ & $127.7^{\mathrm{b}}$ & $186.2^{\mathrm{a}}$ & $179.7^{\mathrm{a}}$ & $10.0^{\mathrm{c}}$ & $23.2^{\mathrm{b}}$ & $36.0^{\mathrm{a}}$ & $36.1^{\mathrm{a}}$ & $98.8^{\mathrm{c}}$ & $173.3^{\mathrm{b}}$ & $232.9^{\mathrm{a}}$ & $224.3^{\mathrm{a}}$ \\
\hline \multicolumn{13}{|c|}{ 'Muang Kan Khiao' } \\
\hline Boiling & $49.2^{c}$ & $54.2^{\mathrm{c}}$ & $73.7^{\mathrm{b}}$ & $102.2^{\mathrm{a}}$ & $7.1^{\mathrm{c}}$ & $8.7^{\mathrm{bc}}$ & $11.3^{\mathrm{b}}$ & $15.6^{\mathrm{a}}$ & $85.6^{\mathrm{d}}$ & $99.0^{\mathrm{c}}$ & & $147.4^{\mathrm{a}}$ \\
\hline Steaming & $49.2^{\mathrm{d}}$ & $63.0^{\mathrm{c}}$ & $98.1^{\mathrm{b}}$ & $121.3^{\mathrm{a}}$ & $7.1^{\mathrm{c}}$ & $12.4^{\mathrm{b}}$ & $14.5^{\mathrm{b}}$ & $22.2^{\mathrm{a}}$ & $85.6^{\mathrm{d}}$ & $115.3^{\mathrm{c}}$ & $156.8^{\mathrm{b}}$ & $188.3^{\mathrm{a}}$ \\
\hline Microwaving & $49.2^{\mathrm{c}}$ & $114.3^{\mathrm{b}}$ & $229.6^{\mathrm{a}}$ & $233.6^{\mathrm{a}}$ & $7.1^{\mathrm{c}}$ & $20.4^{\mathrm{b}}$ & $32.2^{\mathrm{a}}$ & $33.5^{\mathrm{a}}$ & $85.6^{\mathrm{c}}$ & $165.7^{\mathrm{b}}$ & $286.1^{\mathrm{a}}$ & $285.3^{\mathrm{a}}$ \\
\hline
\end{tabular}

Data are expressed as mean $(n=6)$. Values followed by different letters for each combination of cultivar and cooking method are significantly different $(P<0.05)$.

the DPPH radical scavenging assay. All three heating processes increased antioxidant capacities compared with raw fruits, and the fruits heated by microwaving had the highest antioxidant capacities compared with boiling and steaming (Table 1). Heating for $10 \mathrm{~min}$ in a microwave had the highest antioxidant capacity; after that the capacity plateaued (Table 1). 'Muang Lot Fai' had the highest antioxidant capacity (Table 1).

We found that antioxidant capacities of all eggplant cultivars determined by both DPPH and ABTS radical scavenging capacity assay significantly increased with microwaving, steaming and boiling (Table 1). These results are consistent with the work of Dewanto et $\mathrm{al}^{8}$, Turkmen et $\mathrm{al}^{9}$ and Francisco and Resurreccion ${ }^{20}$ who reported that heat treatments enhanced antioxidant capacity in pepper, green bean, broccoli, spinach, sweet corn and peanut (Arachis hypogaea). The results also agree with $\mathrm{Ng}_{\text {et }} \mathrm{al}^{7}$ who found that boiling and microwaving significantly increased antioxidant capacities in water morning glory (Ipomoea aquatica) and bitter gourd (Momordica charantia), respectively. Many antioxidant compounds in plants are mainly present as covalently bound forms with insoluble polymers ${ }^{21}$. It is possible that heat disrupts the cell wall and releases antioxidant compounds, leading to an increase in antioxidant capacity ${ }^{21}$.
It is well known that phenolic compounds are antioxidants ${ }^{1-3}$ which were found in all parts of eggplant $^{3,4}$, and the content of phenolic compounds are changed during cooking ${ }^{8,9}$. In our work, total phenolic content in eggplant cultivars significantly $(p<$ 0.05 ) increased when the fruits were heated for 5,10 , or 15 min with either boiling, steaming, or microwaving compared with raw fruits (Table 1). Microwaving resulted in higher total phenolic content than steaming and boiling methods in all cultivars (Table 1). 'Muang Lot Fai' had the highest total phenolic content which was $1.9,1.7$, and 1.4 times higher than that of 'Muang Lek', 'Muang Kan Dam', and 'Muang Kan Khiao', respectively, at $10 \mathrm{~min}$ of heating. It is interesting to note that although antioxidant capacity and total phenolic content by microwaving for 10 or $15 \mathrm{~min}$ was not significantly different, we found that heating for $15 \mathrm{~min}$ destroyed the texture of fruit and gave an unpleasant shape of fruit (data not shown). For steaming, it was found that the highest total phenolic content for cultivars 'Muang Lek' and 'Muang Kan Dam' were $10 \mathrm{~min}$, whereas the cultivars 'Muang Lot Fai' and 'Muang Kan Khiao' had the highest total phenolic content at $15 \mathrm{~min}$ (Table 1). For boiling, 'Muang Lek' and 'Muang Kan Dam' showed the highest total phenolic content when fruits were heated for $10 \mathrm{~min}$, whereas 'Muang Lot Fai' and 'Muang 

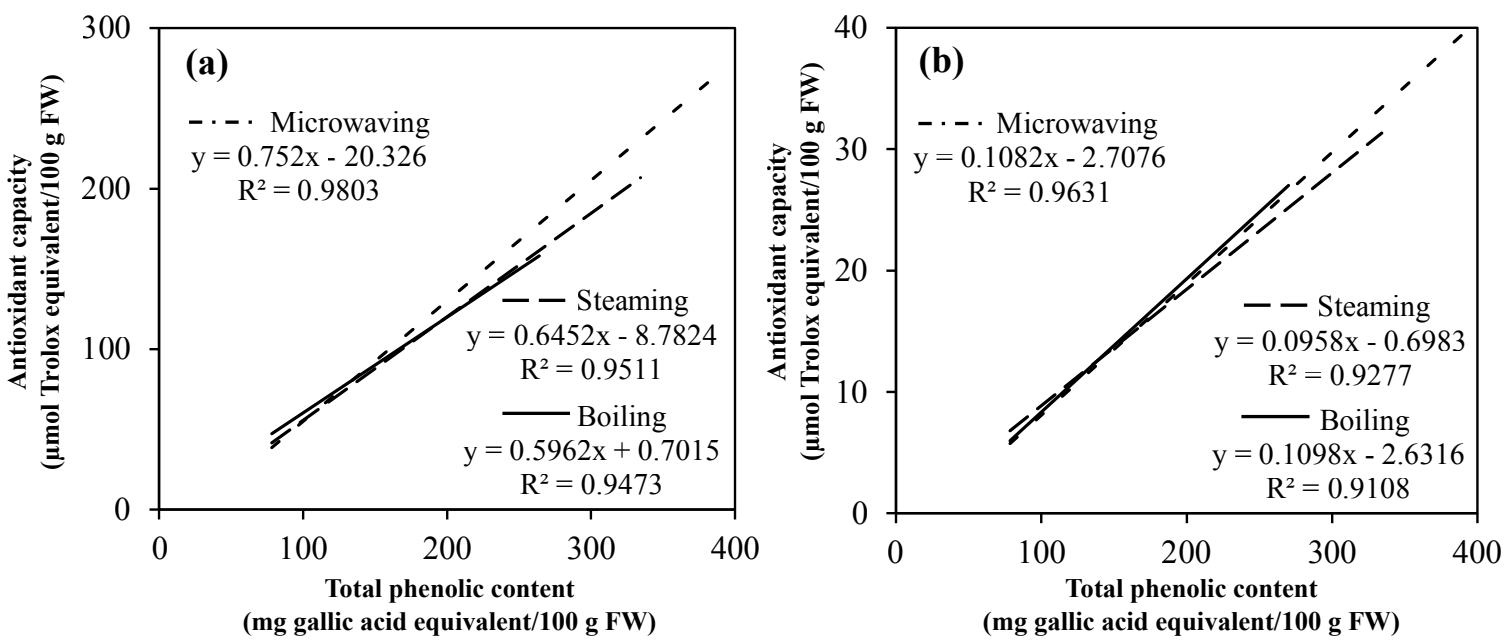

Fig. 2 Correlation between antioxidant capacity and total phenolic content of four cultivars of eggplant fruits using (a) the DPPH method or (b) the ABTS method.

Kan Khiao' had the highest at 15 min (Table 1). An increase in total phenolic content by steaming was higher than by boiling.

The result is in agreement with Dewanto et $\mathrm{al}^{8}$ and Turkmen et $\mathrm{al}^{9}$ who reported that total phenolic content of pepper, green bean, broccoli, spinach, and sweet corn increased after boiling, steaming, or microwaving. Our results also agree with the work of Ornelas-Paz et al ${ }^{10}$ who showed that total phenolic content in pungent peppers was increased by boiling and grilling. Similarly, our finding correlates with $\mathrm{Ng}$ et $\mathrm{al}^{7}$ who reported that boiling and microwaving significantly increased water-soluble phenolic content in water morning glory and bitter gourd. Our results could be possibly explained that boiling, steaming and microwaving change bound phenolic compounds to be free forms and released into cytosol ${ }^{8,21}$. Ju et $\mathrm{al}^{22}$ found that phenolic acids such as vanillic acid, protocatechuic acid, syringic acid, and 2,5-dihydroxyterephthalic acid in Chaga mushroom (Inonotus obliquus) significantly increased after steaming. These authors suggested that the liberation of phenolic compounds was enhanced by steaming.

A highly positive correlation of each heat treatment was found between antioxidant capacity by DPPH and ABTS radical scavenging assay and total phenolic content. For DPPH radical scavenging assay, microwaving had the highest correlation $\left(R^{2}=0.9803\right)$, followed by steaming $\left(R^{2}=0.9511\right)$, and boiling $\left(R^{2}=0.9473\right)$, respectively (Fig. 2a). Similarly, microwaving had the highest correlation $\left(R^{2}=0.9631\right)$, followed by steaming $\left(R^{2}=0.9277\right)$, and boiling $\left(R^{2}=0.9108\right)$, respectively, for ABTS radical scavenging assay (Fig. 2b). This suggests that increasing amounts of phenolic compounds directly enhanced radical scavenging capacity ${ }^{22}$. The result is consistent with the work of Akanitapichat et $\mathrm{al}^{2}$, Huang et $\mathrm{al}^{4}$, and Singh et $\mathrm{al}^{23}$.

The different levels of antioxidant capacity in fruits and vegetables depends on plant cultivars and cooking methods ${ }^{2,4,7,23-25}$. We found that microwaving caused the highest antioxidant capacity, followed by steaming, and boiling. The possible reason is that phenolic and antioxidant compounds activated by microwaving were retained in eggplant fruits, whereas cooking by boiling and steaming processes released them to water, as fruits heated with these two methods have direct and indirect contact with hot water, respectively. Our explanation is supported by comparing results between boiling and steaming methods in which steaming had higher total phenolic content than boiling (Table 1). In addition, heating fruits in a microwave oven increased temperature faster than other heating methods ${ }^{25}$. This destroyed cell membranes of wild blueberries (Vaccinium angustifolium) and allowed antioxidants to be easily extracted from the fruits ${ }^{26}$. Our result agrees with Chuah et $\mathrm{al}^{24}$ who reported that cooking peppers by microwaving had more antioxidants than stir-frying and boiling. Microwaving for $10 \mathrm{~min}$ was the best method in enhancing antioxidant capacity, total phenolic content and having agreeable appearance for eating eggplant fruits, which was highest in 'Muang Lot Fai'.

In conclusion, our results showed that boiling, steaming and microwaving for 5-15 min increased total phenolic contents and antioxidant capacities in 
all eggplant cultivars. 'Muang Lot Fai' had the highest antioxidant level. Microwaving for 10 min produced the highest level of total phenolic compounds and antioxidant capacity. Microwave cooking for $10 \mathrm{~min}$ is best to enhance the antioxidant capacity of eggplant fruits. Further studies are needed to identify and quantify phenolic composition of eggplant fruits after being heated.

Acknowledgements: We would like to thank Dr J.F. Maxwell of the Biology Department, Faculty of Science, Chiang Mai University for reviewing and improving the manuscript. This study was financially supported by a grant from the Faculty of Science, Chiang Mai University, Thailand.

\section{REFERENCES}

1. Cao G, Sofic E, Prior RL (1996) Antioxidant capacity of tea and common vegetables. J Agr Food Chem 44, 3426-31.

2. Akanitapichat P, Phraibung K, Nuchklang K, Prompitakkul S (2010) Antioxidant and hepatoprotective activities of five eggplant varieties. Food Chem Toxicol 48, 3017-21.

3. Jung EJ, Bae MS, Jo EK, Jo YH, Lee SC (2011) Antioxidant activity of different parts of eggplant. $\mathrm{J} \mathrm{Med}$ Plant Res 5, 4610-5.

4. Huang HY, Chang CK, Tso TK, Huang JJ, Chang WW, Tsai YC (2004) Antioxidant activities of various fruits and vegetables produced in Taiwan. Int J Food Sci Nutr 55, 423-9.

5. Chanasut U, Rattanapanone N (2006) Antioxidant of phenolic compound and polyphenol oxidase activities of 16 eggplant fruit cultivars after harvesting. Agr Sci J $37,15-8$.

6. Junmatong C, Uthaibutra J, Saengnil K (2008) Antioxidant activity and total phenolic content in skin and pulp of eggplant fruits. Agr Sci J 39, 384-7.

7. Ng ZX, Chai JW, Kuppusamy UR (2011) Customized cooking method improves total antioxidant activity in selected vegetables. Int J Food Sci Nutr 62, 158-63.

8. Dewanto V, Wu X, Liu RH (2002) Processed sweet corn has higher antioxidant activity. J Agr Food Chem 50, 4959-64.

9. Turkmen N, Sari F, Velioglu YS (2005) The effect of cooking methods on total phenolics and antioxidant activity of selected green vegetables. Food Chem $\mathbf{9 3}$, 713-8.

10. Ornelas-Paz JDJ, Martínez-Burrola JM, Ruiz-Cruz S, Santana-Rodríguez V, Ibarra-Junquera V, Olivas GI, Pérez-Martínez JD (2010) Effect of cooking on the capsaicinoids and phenolics contents of Mexican peppers. Food Chem 119, 1619-25.

11. Sahlin E, Savage GP, Lister CE (2004) Investigation of the antioxidant properties of tomatoes after processing. J Food Compos Anal 17, 635-47.
12. Zhang D, Hamauzu Y (2004) Phenolics, ascorbic acid, carotenoids and antioxidant activity of broccoli and their changes during conventional and microwave cooking. Food Chem 88, 503-9.

13. Wangcharoen W, Morasuk W (2009) Effect of heat treatment on the antioxidant capacity of garlic. Maejo Int J Sci Tech 3, 60-70.

14. Ahmed HA, Osama YA (2008) Antioxidant activity of some Jordanian medicinal plants used traditionally for treatment of diabetes. Pakistan J Biol Sci 11, 351-8.

15. Mun'im A, Negishi O, Ozawa T (2003) Antioxidative compounds from Crotalaria sessiliflora. Biosci Biotechnol Biochem 67, 410-4.

16. Barros L, Ferreira MJ, Queirós B, Ferreira ICFR, Baptista $\mathrm{P}$ (2007) Total phenols, ascorbic acid, $\beta$-carotene and lycopene in Portuguese wild edible mushrooms and their antioxidant activities. Food Chem 103, 413-9.

17. Huang D, Ou B, Prior RL (2005) The chemistry behind antioxidant capacity assays. J Agr Food Chem 53, 1841-56.

18. Re R, Pellegrini N, Proteggente A, Pannala A, Yang M, Rice-Evans C (1999) Antioxidant activity applying an improved ABTS radical cation decolorization assay. Free Radic Biol Med 26, 1231-7.

19. Singleton VL, Rossi JR (1965) Colorimetry of total phenolics with phosphomolybdic-phosphotungstic acid reagents. Am J Enol Viticult 16, 144-57.

20. Francisco MLLD, Resurreccion AVA (2009) Total phenolics and antioxidant capacity of heat-treated peanut skins. J Food Compos Anal 22, 16-24.

21. Choi Y, Lee SM, Chun J, Lee HB, Lee J (2006) Influence of heat treatment on the antioxidant activities and polyphenolic compounds of shiitake (Lentinus edodes) mushroom. Food Chem 99, 381-7.

22. Ju HK, Chung HW, Hong SS, Park JH, Lee J, Kwon SW (2010) Effect of steam treatment on soluble phenolic content and antioxidant activity of the Chaga mushroom (Inonotus obliquus). Food Chem 119, 619-25.

23. Singh AP, Luthria D, Wilson T, Vorsa N, Singh V, Banuelos GS, Pasakdee S (2009) Polyphenols content and antioxidant capacity of eggplant pulp. Food Chem 114, 955-61.

24. Chuah AM, Lee YC, Yamaguchi T, Takamura H, Yin LJ, Matoba T (2008) Effect of cooking on the antioxidant properties of coloured peppers. Food Chem 111, $20-8$.

25. Sun T, Tang JM, Powers JR (2007) Antioxidant activity and quality of asparagus affected by microwavecirculated water combination and conventional sterilization. Food Chem 100, 813-9.

26. Murphy RR, Renfroe MH, Brevard PB, Re RE, Gloeckner JW (2009) Cooking does not decrease hydrophilic antioxidant capacity of wild blueberries. Int J Food Sci Nutr 60, 88-98. 